\title{
Persepsi Mahasiswa Terhadap Berita Pada Website APTISI
}

\section{Student Perception to the News on The APTISI Website}

\author{
Untung Rahardja ${ }^{1}$, Ninda Lutfiani ${ }^{2}$, Resti Rahmawati ${ }^{3}$ \\ Dosen STMIK Raharja ${ }^{1}$, Mahasiswa STMIK Raharja Program Studi Magister Teknik \\ Informatika $^{2}$, Mahasiswa STMIK Raharja Program Studi Sistem Informasi ${ }^{3}$

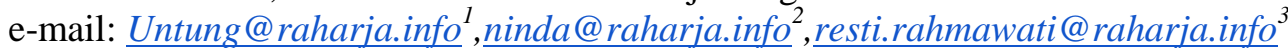

\begin{abstract}
Abstrak
Mahasiswa pasti mengenal adanya portal berita. Sebagian besar membaca atau menyimak berita hanya karena mereka tertarik dengan judul atau topik yang sedang tenar. Terlebih untuk berita yang berhubungan dengan asosiasi. Hal utama dari tidak seringnya mahasiswa mengunjungi website suatu asosiasi adalah karena kurangnya paham terhadap apa yang sebenarnya dijelaskan dalam berita yang ada. Sebetulnya, dalam berita asosiasi tidak hanya diperuntukkan para rektor atau dosen, banyak juga berita yang sangat bermanfaat untuk dapat diketahui oleh mahasiswa. Misalnya untuk berita mengenai Perguruan Tinggi mereka, informasi seminar, dan workshop. Dari permasalahan yang ada, peneliti mengambil tema penelitian bagaimana tanggapan mahasiswa terhadap berita yang ada pada website asosiasi, khususnya untuk website aptisi.or.id. Dengan judul Persepsi Mahasiswa Terhadap Berita Pada Website APTISI. Populasi dalam penelitian ini adalah mahasiswa STMIK Raharja. Penelitian ini bersifat kuantitatif dengan data yang diambil dari kuesioner. Kuesioner yang dibagikan berbentuk google form. Responden yang ditargetkan pada penilitian ini berjumlah 30, dan respon yang didapatkan terkumpul 39 responden, terdiri dari 10 pernyataan, dibagi menjadi 2 yaitu bagian website dan bagian berita atau konten. Masing-masing bagian terdiri dari 5 pernyataan. Metode perhitungan yang diterapkan pada penelitian ini menggunakan perhitungan skala likert. Hasil pada bagian website menunjukkan persentase sebesar $79 \%$ dan termasuk ke dalam kategori setuju, artinya mahasiswa mendukung adanya website aptisi.or.id dan menyajikan berita yang up to date. Sedangkan hasil pada bagian berita dan konten sebesar 79,6\% dan termasuk ke dalam kategori setuju, yang menunjukkan bahwa mahasiswa setuju dengan adanya berita pada website aptisi.or.id dapat memberikan manfaat untuk mereka. Kalkulasi hasil penelitian menunjukkan bahwa responden menyatakan setuju dengan adanya website APTISI yang baru.
\end{abstract}

Kata kunci-Berita, website asosiasi, persepsi mahasiswa

Abstract

A student must be familiar with the news portal. Most read or listen to news just because they are interested in a title or topic that is famous. Especially for news related to the association. The main thing about the inaccessibility of a student visiting an association's website is due to a lack of understanding of what is actually explained in the news. In fact, in the news of the association is not only intended for rectors or lecturers, many news that is very useful to be known by students. For example for news about their Universities, seminar information, and workshops. From the existing problems, researchers took the theme of research how the student responses to the news on the website association, especially for aptisi.or.id website. With the title of Student Perception Against News On Website APTISI. The 
population in this research are students STMIK Raharja. This research is quantitative which data taken by questionnaire. Questionnaire given in the form of google form. Respondents targeted at this research amounted to 30, and the results obtained amounted to 39 respondents, with 10 statements divided into 2 parts, namely the website and news or content section. Each section consists of 5 statements. Method used in this research uses Likert Scale. The results on the website show a percentage of 79\% and fall into the agreed category, meaning that students support the website aptisi.or.id and present up to date news. While the results on the news and content of $79.6 \%$ and included in the category agree, which indicates that students agree with the news on the website aptisi.or.id can provide benefits to them. Calculation of research results indicate that the respondents agreed with the new APTISI website.

Keywords-News, association website, student perception

\section{PENDAHULUAN}

Setiap asosiasi tentunya ingin keberadaannya dapat dikenal dan diterima oleh lingkungan mereka terutama pada lingkungan mahasiswa. Lingkungan asosiasi merupakan pihak-pihak yang memiliki kepentingan atau publik dari organisasi itu sendiri. Oleh sebab itu, organisasi membutuhkan sesuatu yang dapat menjadi penunjang untuk menaikkan eksistensi mereka.

Asosiasi Perguruan Tinggi Swasta (APTISI) merupakan organisasi yang menampung seluruh Perguruan Tinggi Swasta Indonesia dan seluruh Badan Hukum Penyelenggara Perguruan Tinggi Swasta (BHP-PTS) di seluruh Indonesia. Organisasi APTISI telah terdaftar di Direktorat Jenderal Sosial Politik, Departemen Dalam Negeri (Depdagri) No.123 tahun 1999.

Web merupakan sebuah sistem informasi yang disajikan dalam bentuk teks, gambar, suara dan lain-lain yang tersimpan dalam sebuah server web internet yang disajikan dalam bentuk hiperteks (Simarmata, 2010). ${ }^{[1]}$

Website merupakan situs sistem informasi yang dapat diakses dengan cepat. Website lahir dari adanya perkembangan zaman saat ini dari bidang teknologi informasi dan komunikasi. Website telah menjadi media penyampaian informasi bagi bermacam perusahaan, sekolah, tidak terkecuali pada organisasi.

Website asosiasi merupakan salah satu bentuk pemanfaatan teknologi internet bagi perusahaan maupun organisasi untuk menyediakan informasi yang efektif dan efisien. Pada website asosiasi tentunya menyajikan data atau informasi yang berkaitan dengan asosiasi tersebut. Salah satu bagian paling penting dari website asosiasi adalah adanya sebuah berita atau artikel. Penyampaian informasi berupa berita ini terkadang dianggap remeh oleh kumpulan mahasiswa, karena sebagian besar tidak terlalu ingin mengetahui persoalan asosiasi yang sifatnya non-akademik.

Khairunnisa (2010) menyatakan bahwa informasi merupakan data penting yang memberikan pengetahuan berguna. Kegunaan informasi tergantung pada : tujuan si penerima, ketelitian penyampaian dan pengolahan data, waktu, ruang dan tempat, bentuk, semantik. ${ }^{[2]}$

Kebutuhan informasi yang tinggi mengarahkan masyarakat kepada harapan media yang cepat dalam menyajikan informasi sehingga masyarakat lebih mudah dalam mengambil suatu keputusan yang berkaitan dengan kepentingan dari permasalahan yang ada. 


\begin{tabular}{lllll}
\hline C (1) aptisiorid & & & \\
LOGIN PROFLL & STRUKTUR ORGANISASI & VISI DAN MISI & MARS APTISI & PENDAFTARAN \\
FORM REQUEST EMAIL & & & \\
\hline
\end{tabular}
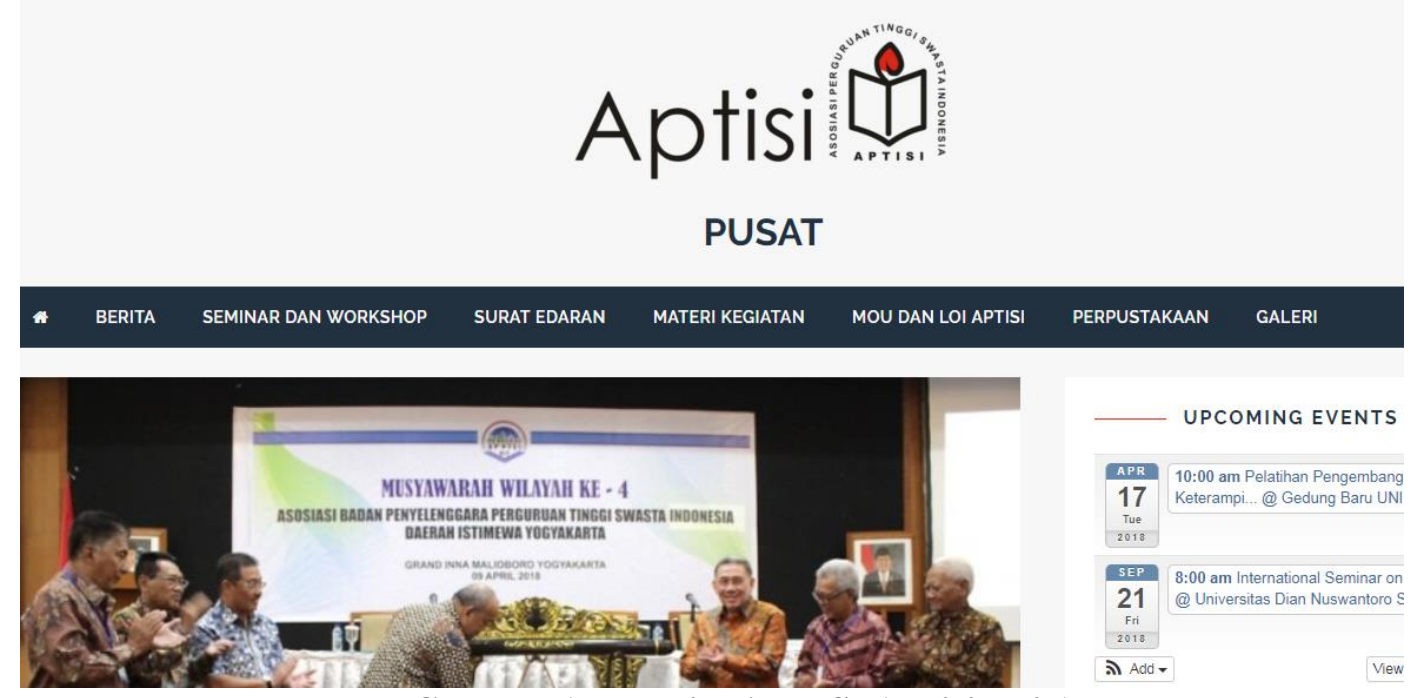

\section{Gambar 1. Website APTISI (aptisi.or.id) Sumber :http://aptisi.or.id/, 2017}

Gambar 1. di atas merupakan tampilan awal website APTISI yang baru dengan domain aptisi.or.id. Terlihat lebih responsif dari website sebelumnya, dari tampilan home langsung menunjukkan berita yang update.

Berita adalah kumpulan informasi berupa teks, ucapan maupun gambar yang dibutuhkan oleh manusia untuk menambah dan memperbaharui wawasan atau informasi yang dimilikinya. Pada website aptisi.or.id tentunya memberikan informasi berupa artikel atau berita terbaru mengenai Asosiasi Perguruan Tinggi Swasta Indonesia (APTISI). Berita yang ada pada website tidak hanya seputar Perguruan Tinggi, tetapi dapat mencakup seputar mahasiswa, seminar nasional atau sesuatu yang berhubungan dengan himbauan-himbauan kepada mahasiswa, dan kegiatan yang dilakukan untuk setiap daerah yang tergabung dalam APTISI.

\section{* BERITA SEMINAR DAN WORKSHOP SURAT EDARAN MATERI KEGIATAN}

\section{Berita}

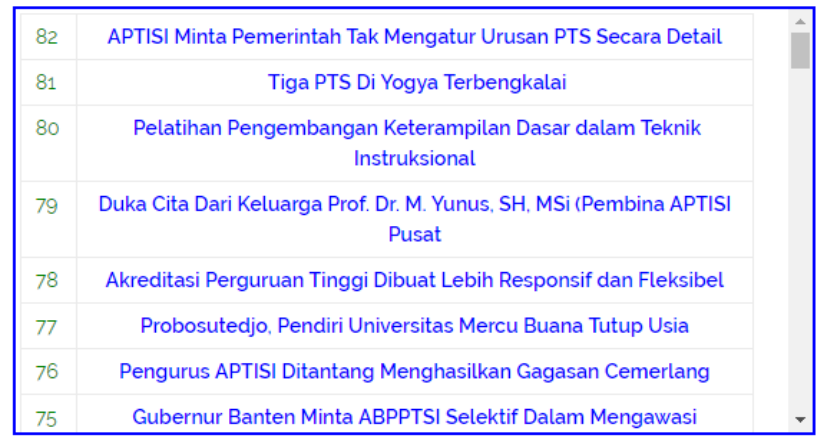

Gambar 2. Rangkaian Berita aptisi.or.id

Sumber : http://aptisi.or.id/berita/ 
Gambar 2. menunjukkan tampilan keseluruhan berita dari page berita. Ditata dalam bentuk tabel yang digunakan untuk mempermudah jika ingin membaca semua berita yang ada di website, semua terangkum dalam satu page dan hanya dengan melakukan scroll down sudah dapat membaca keseluruhan berita.

Saat ini mahasiswa memandang sebelah mata terhadap asosiasi atau organisasi yang bergerak di bidang non-akademik. Kenyataannya hanya beberapa mahasiswa yang mengetahui adanya Asosiasi Perguruan Tinggi Swasta Indonesia (APTISI). Dengan adanya perancangan website aptisi.or.id diharapkan mampu memberikan pengetahuan seputar Perguruan Tinggi Swasta Indonesia dan memperkenalkan secara luas aptisi.or.id kepada publik khususnya mahasiswa.

Biasanya mahasiswa membaca atau melihat dari kaya atau tidaknya informasi dari sebuah website. Website dapat dikatakan kaya akan informasi apabila mengandung kaya informasi yang bersifat fakta. Dengan website berisi konten yang banyak memberikan informasi, menjadikan sebuah website lebih unggul dan lebih terkenal. ${ }^{[3]}$ Barnes \& Vidgen (2002:115) menyatakan bahwa "untuk mengetahui kualitas sebuah website secara keseluruhan, ada tiga dimensi yang harus diteliti, yaitu : Usability Quality, Web Information Quality, dan Site Design Quality.

Pada website APTISI sebelumnya, terlihat belum adanya informasi yang lengkap mengenai aktivitas yang dilakukan asosiasi tersebut. Nampaknya, website yang lama ini sudah tidak lagi dikendalikan oleh seorang admin, sehingga menjadikan website APTISI yang lama menjadi terbengkalai. Mengingat pentingnya sebuah informasi terutama dalam berita yang ada pada website, dalam berita ter-update yang ada di website dapat menunjukkan salah satu tandatanda bahwa website tersebut dapat dikatakan masih aktif.

\section{METODE PENELITIAN}

Metode dapat diartikan sebagai proses, cara atau prosedur yang digunakan untuk memecahkan suatu masalah. Metode pengumpulan data yang dilakukan pada tahap ini, menggunakan 2 (dua) metode yaitu : Metode Studi Pustaka dan Metode Kuesioner.

\section{Metode Studi Pustaka}

Studi Pustaka merupakan metode yang digunakan untuk mengumpulkan informasi yang relevan sesuai dengan topik dan permasalahan yang menjadi obyek penelitian. Informasi yang diperoleh dari buku, karya ilmiah, sumber literature review, makalah, internet yang berhubungan dengan penelitian yang dilakukan sebagai bahan referensi. Adapun 10 (sepuluh) referensi jurnal yang didapat untuk pembuatan jurnal ini:

a. Penelitian yang telah dilakukan oleh Zaqqiyatul Ifadah, Ainur Rochmaniah (2014) berjudul "Opini Mahasiswa Terhadap Website Universitas Muhammadiyah Sebagai Media Informasi" "4]. Pada penelitian yang dilakukan, dinyatakan hasil akhir bahwa website Universitas Muhammadiyah Sidoarjo sebagai media informasi ialah kurang baik dari segi kualitasnya. Respon yang diberikan oleh responden terhadap website Universitas Muhammadiyah Sidoarjo sebagai media informasi kurang baik.

b. Penelitian yang telah dilakukan oleh Annisa Febrina (2014) berjudul "Opini Mahasiswa Universitas Sumatera Utara Terhadap Instagram @kulinermedan, "[5]. Hasil responden menunjukkan bahwa instagram @kulinermedan baik. Menurut responden instagram tersebut dianggap sangat menarik dan kreatif sebagai media informasi kuliner. Manfaat lain yang didapat oleh para mahasiswa Universitas Sumatera Utara adalah kemudahan dalam menentukan kuliner yang cocok dengan yang mereka inginkan.

c. Penelitian yang telah dilakukan oleh Dyva Yulisda br Purba dan MC Ninik Sri Rejeki (2014) berjudul "Pengaruh Kualitas Website Terhadap Citra (Studi Kuantitatif Kualitas Website Pemerintah Kota Yogyakarta Terhadap Citra Pemerintah Kota Yogyakarta), 
Penelitiannya dilakukan untuk mengetahui dampak antara kualitas website terhadap citra sebuah organisasi. Penelitian dilakukan pada website Pemerintah Kota Yogyakarta, responden pada penelitian tersebut adalah para pengakses website Pemerintah Kota Yogyakarta (jogjakota.go.id). Metode penelitian yang dilakukan adalah kuantitaif dengan menyebarkan kuesioner sebagai cara untuk mengetahui dampaknya. Hasil penelitiannya menunjukkan bahwa media komunikasi berupa website mempengaruhi citra organisasi, serta desain yang digunakan website.

d. Penelitian yang telah dilakukan oleh Ghani Pradita, Sunarru Samsi Hariadi, Harsoyo (2015) berjudul "Respons Mahasiswa Terhadap Website Purnama Jaya Farm Sleman" [7]. Pengambilan sampel jurusan dilakukan secara purposif, sedangkan pengambilan sampel mahasiswa dilakukan secara acak. Total sample berjumlah 64 mahasiswa jurusan Sosial Ekonomi Pertanian dari angkatan 2010 hingga 2013. Dari setiap angkatan diambil 16 responden diantaranya 8 mahasiswa Agribisnis dan 8 mahasiswa Penyuluhan dan Komunikasi Pertanian. Metode perhitungannya dengan menggunakan pengujian proporsi dan analisis regresi linear berganda.

e. Penelitian yang telah dilakukan oleh Wahyu Wido Sari (2014) berjudul "Persepsi Guru dan Siswa SD di Yogyakarta terhadap Program Conservation Scout" ${ }^{[8]}$. Penelitian yang dilakukan untuk mengetahui respon sekolah terhadap program conservation scout. Metode perhitungan yang diterapkan adalah action research, survey, dan deskriptif kualitatif. Instrumennya menggunakan kuesioner dengan hasil validasi sangat baik.

f. Penelitian yang telah dilakukan oleh Anggita Langgeng Wijaya (2016) berjudul "Persepsi Mahasiswa Pendidikan Akuntansi Tentang Kurikulum Akuntansi Syariah" ${ }^{[9]}$. Penelitiannya bersifat deskriptif dengan hasil yang diambil dengan kuesioner. Sampelnya terdiri dari 92 mahasiswa kelas teori akuntansi. Hasilnya menunjukkan bahwa mahasiswa menilai kurikulum akuntansi syariah penting untuk diberikan kepada mahasiswa program studi pendidikan akuntansi karena dinilai penting bagi mahasiswa sebagai tambahan ilmu pengetahuan baru dan mendukung karir mahasiswa di masa depan.

g. Penelitian yang telah dilakukan oleh Pradipta Angga Saputra dan Adi Nugroho (2017) berjudul "Perancangan dan Implementasi Survey Kepuasan Pengunjung Berbasis Web Di Perpustakaan Daerah Kota Salatiga" $[10]$. Hasil yang didapatkan selama ini yaitu memberikan kuesioner kepada pelanggan. Hasil kepuasan pelanggan yang terintegrasi dengan internet akan memudahkan pelanggan untuk mengisi kuesioner di mana saja dan kapan saja selama periode tertentu.

h. Penelitian yang telah dilakukan oleh Nur Khasan, Bambang Soedijono W A, Hanif Al Fatta (2016) berjudul "Analisis Sistem Informasi Manajemen Pendidikan Dalam Perspektif Human Computer Interaction" $[11]$. Metode analisisnya menggunakan Regresi Linear Bergandengan dengan menggunakan software SPSS versi 22 yang digunakan untuk pengujian hipotesis H1 hingga H5. Jenis penelitian bersifat asosiatif kausal. Penelitian asosiasi kausal merupakan penelitian untuk mengetahui hasil analisis hubungan antara satu variabel dan variabel lainnya. Pengujian yang dilakukan menggunakan kuesioner. Skala perhitungan menggunakan Skala Likert, skala yang dipakai untuk mengukur opini atau persepsi orang atau sekelompok. Dengan jawaban diberi penilaian 1 sampai 5 tanggapan yang paling positif (sangat setuju) bernilai paling tinggi dan tanggapan paling negatif (sangat tidak setuju) bernilai paling kecil.

i. Penelitian yang telah dilakukan oleh Dimitri Indastri Putra, Arif Bijaksana Putra Negara, Rudy Dwi Nyoto berjudul "Rancang Bangun Sistem Informasi Pengolahan Data Kriminal Berbasis Website Pada Bagian Pembinaan Operasional Direktorat Reserse Kriminal Umum Polda Kalimantan Barat" ${ }^{,[12]}$. Pengujian dilakukan dengan metode blackbox dan kuesioner. Kuesioner dibagikan pada 12 responden. Pengujian kuesioner terbagi dua bagian yaitu, penggunaan aplikasi dan perbandingan. Perhitungan hasil kuesionernya dilakukan menggunakan Skala Likert. 
j. Penelitian yang telah dilakukan oleh Suhar Janti dengan judul "Analisis Validitas dan Reliabilitas Dengan Skala Likert Terhadap Pengembangan SI/TI Dalam Penentuan Pengambilan Keputusan Penerapan Strategic Planning Pada Industri Garmen"[13] . Dalam penelitian ini menggunakan metode kuantitatif dengan SPSS 17, dengan uji validitas dan reliabilitas dengan skala Likert sebagai level pengukuran yang digunakan. Pengambilan sampel dilakukan oleh 50 responden penelitian. Hasil penelitian ini diterima hipotesis pengujian validitas dan reliabilitas pengembangan IS/IT tersebut dirancang untuk pengambilan keputusan yang kemudian dapat digunakan oleh manajemen perusahaan untuk menerapkan strategis perumusan perencanaan IS/IT.

\section{Metode Kuesioner}

Kuesioner merupakan daftar pertanyaan dalam bentuk tertulis yang sudah disusun dengan rangkaian pertanyaan atau pernyataan. Pertanyaan atau pernyataan yang dibuat dijabarkan secara rinci dan lengkap beserta dengan pilihan jawaban atau mempersilahkan responden untuk menjawab secara bebas.

Kuesioner ini dibuat untuk mengetahui seberapa banyak opini mahasiswa tentang pengetahuan mereka terhadap website aptisi.or.id. Penyebaran kuesioner dilakukan dengan cara menyebarkannya secara langsung dengan memberikan link yang berisi kuesioner. Terdapat 10 (sepuluh) pernyataan, 5 pilihan penilaian, dimulai dari (1) sangat tidak setuju, (2) tidak setuju, (3) cukup setuju, (4) setuju dan (5) sangat setuju. Dalam metode ini memanfaatkan google formulir untuk pembuatan kuesionernya.

\section{HASIL DAN PEMBAHASAN}

Hasil penelitian akan disajikan berupa tabel data yang diperoleh dari hasil pengisian responden terhadap kuesioner yang diberikan. Pada kuesioner ini yang dijadikan target adalah mahasiswa. Banyaknya responden yang ditargetkan adalah 30, dan respon yang terkumpul sebanyak 39. Pada bagian metode ini, pernyataan terbagi 2 bagian, bagian 1 yaitu pernyataan mengenai website dan bagian 2 mengenai berita dan konten.

\section{Skala Likert}

Dalam penghitungan hasil kuesioner yang didapat, penulis melakukan penghitungan metode Skala Likert. Skala Likert digunakan untuk menghitung persepsi, opini atau pendapat responden terhadap sebuah peristiwa berdasarkan pernyataan yang telah ditetapkan.

\section{Teknik Pengolahan Kuesioner}

Setelah pernyataan yang diberikan kepada responden berhasil dilakukan, maka selanjutnya dilakukan pengolahan tiap butir kuesioner menggunakan skala likert. Perhitungan ini tidak menggunakan sistem perhitungan SPSS, hanya menggunakan metode skala likert.

\section{Pengolahan Data}

Bagian pengolahan data ini diambil dari hasil responden sebanyak 39 responden dengan dibagikan kuesioner secara online dengan menggunakan google form. Terdapat 10 pernyataan yang terbagi menjadi 2 bagian, yaitu:

1. Bagian Website

Terdapat 5 pernyataan dalam bagian ini, yaitu :

Tabel 1. Pernyataan Bagian Website

\begin{tabular}{ccccccc}
\hline No & Pernyataan & STS & TS & CS & S & SS \\
\hline 1. & Tampilan website menarik & & & & & \\
\hline
\end{tabular}




\begin{tabular}{cl}
\hline 2. & Fitur-fitur dalam website lengkap \\
\hline 3. & Kecepatan website baik \\
\hline 4. & $\begin{array}{l}\text { Memiliki interaksi yang jelas dan } \\
\text { mudah dimengerti }\end{array}$ \\
\hline 5. & Website mudah diakses \\
\hline
\end{tabular}

2. Bagian Berita dan Konten

Terdapat 5 pernyataan dalam bagian ini, yaitu :

Tabel 2. Pernyataan Bagian Berita dan Konten

\begin{tabular}{|c|c|c|c|c|c|c|}
\hline No & Pernyataan & STS & TS & $\mathrm{CS}$ & $S$ & SS \\
\hline 1. & Berita yang dibahas menarik & & & & & \\
\hline 2. & Berita up to date & & & & & \\
\hline 3. & Berita jelas dan terperinci & & & & & \\
\hline 4. & $\begin{array}{l}\text { Bahasa yang digunakan mudah } \\
\text { dimengerti }\end{array}$ & & & & & \\
\hline
\end{tabular}

\section{Penghitungan Skala Likert}

Tabel 3. Penghitungan Nilai Skala

\begin{tabular}{cc}
\hline Skala Jawaban & Nilai Skala \\
\hline STS & 1 \\
\hline TS & 2 \\
\hline CS & 3 \\
\hline S & 4 \\
\hline SS & 5 \\
\hline
\end{tabular}

Keterangan :

$\begin{array}{ll}\text { STS } & =\text { Sangat Tidak Setuju } \\ \text { TS } & =\text { Tidak Setuju } \\ \text { CS } & =\text { Cukup Setuju } \\ \text { S } & =\text { Setuju } \\ \text { SS } & \text { S Sangat Setuju }\end{array}$

\section{Interpretasi Skor Perhitungan}

$\mathrm{Y}=$ skala tertinggi likert $\mathrm{x}$ jumlah responden

$\mathrm{X}=$ skala terendah likert $\mathrm{x}$ jumlah responden

Jumlah skala tertinggi untuk item "Sangat Setuju" adalah 5 x $195=975$, sedangkan skala terendah untuk item "Sangat Tidak Setuju" adalah 1 x $195=195$.

\section{Rumus Index \% = Total Skor $/$ Y x 100}

Setelah mengetahui nilai $\mathrm{Y}$, maka selanjutnya perhitungan menggunakan rumus index untuk mengetahui interval (rentang jarak) dan interpretasi persen supaya mengetahui penilaian dengan metode mencari Interval skor persen (I). Rumus index dijabarkan pada setiap bagian pernyataan kuesioner. 


\section{Rumus Interval}

$\mathrm{I}=100 /$ Jumlah Skor (Likert)

Maka $=100 / 5=20$

Hasil $(\mathrm{I})=20$ (hasil interval jarak dari terendah 0\% hingga tertinggi 100\%)

Berikut adalah kriteria interpretasi skornya berdasarkan interval :

- Angka 0\%-19,99\%= Sangat Tidak Setuju

- Angka 20\%-39,99\%= Tidak Setuju

- Angka $40 \%-59,99 \%=$ Cukup Setuju

- Angka $60 \%-79,99 \%=$ Setuju

- Angka $80 \%-100 \%=$ Sangat Setuju

\section{Pengolahan Data Setiap Bagian Kuesioner}

Pengolahan Kuesioner Untuk Bagian Website

Terdapat 5 pernyataan dengan tiap pernyataan diisi oleh 39 responden. Maka keseluruhan bagian ini berhasil mengumpulkan 195 respon. Masing-masing yang menjawab STS adalah 4 responden, yang menjawab TS adalah 14 responden, yang menjawab CS adalah 35 responden, yang menjawab S adalah 76 responden dan yang menjawab SS adalah 66 responden.

Tabel 4. Penjabaran Respon yang Didapat

\begin{tabular}{cc}
\hline Skala Jawaban & Frekuensi \\
\hline STS & 4 \\
\hline TS & 14 \\
\hline CS & 35 \\
\hline S & 76 \\
\hline SS & 66 \\
\hline
\end{tabular}

a. Rumus T x Pn

Tabel 5. Pengolahan Kuesioner Bagian Website

\begin{tabular}{ccc}
\hline Skala Jawaban & T x Pn & Hasil \\
\hline STS & $4 \times 1$ & 4 \\
\hline TS & $14 \times 2$ & 28 \\
\hline CS & $35 \times 3$ & 105 \\
\hline S & $76 \times 4$ & 304 \\
\hline SS & $66 \times 5$ & 330 \\
\hline
\end{tabular}

Keterangan :

$\mathrm{T}=$ Total jumlah responden yang memilih

Pn $=$ Pilihan angka skor Likert 


\section{b. Perhitungan Akhir}

Dari hasil diatas maka total perhitungan skornya adalah $\mathbf{4 + 2 8 + 1 0 5 + 3 0 4 + 3 3 0 = 7 7 1}$.

\section{Rumus Index $100 \%=$ Total Skor $/$ Y $\times 100$$$
=771 / 975 \times 100
$$$$
=79 \%
$$

Jadi, hasil tersebut menunjukkan bahwa skor $79 \%$ termasuk ke dalam kategori "Setuju".

\section{Pengolahan Kuesioner Untuk Bagian Berita dan Konten}

Terdapat 5 pernyataan dengan tiap pernyataan diisi oleh 39 responden. Maka keseluruhan bagian ini berhasil mengumpulkan 195 respon. Masing-masing yang menjawab STS adalah 5 responden, yang menjawab TS adalah 11 responden, yang menjawab CS adalah 29 responden, yang menjawab $\mathrm{S}$ adalah 88 responden dan yang menjawab SS adalah 62 responden.

Tabel 6. Penjabaran Respon yang Didapat

\begin{tabular}{|c|c|}
\hline Skala Jawaban & Frekuensi \\
\hline STS & 5 \\
\hline TS & 11 \\
\hline CS & 29 \\
\hline S & 88 \\
\hline SS & 62 \\
\hline
\end{tabular}

a. Rumus T x Pn

Tabel 7. Pengolahan Kuesioner Bagian Berita dan Konten

\begin{tabular}{|c|c|c|}
\hline Skala Jawaban & T x Pn & Hasil \\
\hline STS & $5 \times 1$ & 5 \\
\hline TS & $11 \times 2$ & 22 \\
\hline CS & $29 \times 3$ & 87 \\
\hline S & $88 \times 4$ & 352 \\
\hline SS & $62 \times 5$ & 310 \\
\hline
\end{tabular}

Keterangan :

$\mathrm{T}=$ Total jumlah responden yang memilih

Pn $=$ Pilihan angka skor Likert 


\section{b. Perhitungan Akhir}

Dari hasil diatas maka total perhitungan skornya adalah $\mathbf{5}+\mathbf{2 2}+\mathbf{8 7}+\mathbf{3 5 2 + 3 1 0}=\mathbf{7 7 6}$.

$\begin{aligned} \text { Rumus Index 100\% } & =\text { Total Skor } / \text { Y } \times 100 \\ & =776 / 975 \times 100 \\ & =79,6 \%\end{aligned}$

Jadi, hasil tersebut menunjukkan bahwa skor $79,6 \%$ termasuk ke dalam kategori "Setuju".

Berdasarkan dari hasil kuesioner yang diberikan kepada 39 responden dengan 10 pernyataan, terdapat hasil akhir untuk 2 (dua) bagian, yaitu bagian website dan bagian berita atau konten. Untuk hasil akhir bagian website didapatkan persentase $79 \%$ berada dalam skala interval setuju. Yang artinya responden setuju dengan adanya website APTISI yang baru, karena terlihat jelas bahwa website yang baru ini lebih responsif dan user friendly. Sedangkan hasil akhir dari bagian berita atau konten didapatkan persentase sebesar 79,6\% berada dalam skala interval setuju. Dapat diartikan bahwa responden setuju dengan berita atau konten yang disajikan, baik secara bahasa maupun manfaatnya.

\section{KESIMPULAN}

Hasil perhitungan di atas menunjukkan bahwa mahasiswa setuju terhadap pembangunan website APTISI yang baru. Dengan adanya website yang baru ini menunjukkan keaktifan yang nyata dalam sebuah website, misalnya dengan update news setiap harinya. Tidak hanya diukur dari segi website, namun terdapat juga perhitungan dari segi berita atau konten yang disajikan, mahasiswa setuju bahwa berita atau konten yang disajikan bermanfaat dan lebih baik daripada sebelumnya yang hanya terfokuskan untuk rektor atau dosen.

\section{SARAN}

Website aptisi.or.id belum memiliki website yang saling terhubung satu sama lain antara wilayah 1 sampai dengan 13 wilayah yang tergabung dalam APTISI. Sehingga menyulitkan untuk mendapatkan informasi yang sedang dilakukan pada setiap wilayah.

\section{UCAPAN TERIMA KASIH}

Peneliti mengucapkan banyak terimakasih kepada para pihak yang telah membantu dalam menyelesaikan penelitian ini. Terutama kepada Tuhan Yang Maha Esa, karena berkat rahmat dan hidayah-Nya sehingga dapat menyelesaikan penelitian ini. Juga tak lupa peneliti mengucapkan terimakasih kepada penulis 1 (satu) dan penulis 2 (dua) yang mana juga sebagai pembimbing selama penelitian berlangsung yang telah memberikan arahannya dalam penulisan. Terpenting peneliti juga mengucapkan terimakasih kepada STMIK Raharja yang telah menyediakan tempat dalam proses penyelesaian jurnal ini. Juga kepada seluruh responden yang sudah membantu peneliti dalam memberikan responnya terhadap kuesioner yang telah dibagikan. Dalam penulisan penelitian ini tentunya peneliti menyadari masih banyak kekurangan karena keterbatasan yang peneliti miliki. 


\section{DAFTAR PUSTAKA}

[1] Simarmata, Janner., 2009, Perancangan Basis Data Edisi 1, Andi, Yogyakarta.

[2] Khairunnisa, Sarah., 2010, Perilaku Penemuan Informasi Atlet Puslatcab Surabaya dalam Menunjang Prestasi Di Bidang Non Akademik (Studi Deskriptif Kuantitaif Perilaku Penemuan Informasi Atlet Taekwondo Puslatcab Surabaya dalam Menunjang Prestasi. Surabaya.

[3] Barnes, S \& Vidgen, R., 2002, An Integrative Approach To The Assessment Of ECommerce Quality. Journal of Electronic Commerce Research, VOL. 3, NO. 3: 114-127.

[4] Ifadah Zaqqiyatul, dan Ainur Rochmaniah., 2014, Opini Mahasiswa Terhadap Website Universitas Muhammadiyah Sidoarjo Sebagai Media Informasi, VOL.2, No.2.

[5] Febrina Annisa., 2014, Opini Mahasiswa Universitas Sumatera Utara Terhadap Instagram@kulinermedan.

[6] Yulisda br Purba Dyva, dan MC Ninik Sri Rejeki., 2014, Pengaruh Kualitas Website Terhadap Citra (Studi Kuantitatif Kualitas Website Pemerintah Kota Yogyakarta Terhadap Citra Pemerintah Kota Yogyakarta), Yogyakarta.

[7] Pradita Ghani, Sunarru Samsi Hariadi, dan Harsoy., 2015, Respons Mahasiswa Terhadap Website Purnama Jaya Farm Sleman, VOL.26, NO.1.

[8] Sari WW., 2014, Persepsi Guru dan Siswa SD di Yogyakarta terhadap Program Conservation Scout", Vol. 2 No.

[9] Wijaya AL., 2016, Persepsi Mahasiswa Pendidikan Akuntansi Tentang Kurikulum Akuntansi Syariah.

[10] Saputra Pradipta Angga, dan Adi Nugroho., 2017, Perancangan dan Implementasi Survey Kepuasan Pengunjung Berbasis Web Di Perpustakaan Daerah Kota Salatiga, Volume 15 , No. 1.

[11] Khasan Nur, Bambang Soedijono, dan Hanif Al Fatta., 2016, Analisis Sistem Informasi Manajemen Pendidikan Dalam Perspektif Human Computer Interaction, Vol. 9 No. 2.

[12] Putra Dimitri Indastri, Arif Bijaksana Putra Negara, Rudy Dwi Nyoto., 2017, Rancang Bangun Sistem Informasi Pengolahan Data Kriminal Berbasis Website Pada Bagian Pembinaan Operasional Direktorat Reserse Kriminal Umum Polda Kalimantan Barat, Vol. 5, No. 4.

[13] Janti, S., 2014, November, Analisis Validitas Dan Reliabilitas Dengan Skala Likert Terhadap Pengembangan Si/Ti Dalam Penentuan Pengambilan Keputusan Penerapan Strategic Planning Pada Industri Garmen, In Prosiding Seminar Nasional Aplikasi Sains \& Teknologi (SNAST), Vol. 15, pp. 155-160. 